\title{
Violence Against Women and Perceived Health: An Observational Survey of Consultants in Family Planning Centers in the Paris, France, Region.
}

\author{
Yélian Ahogbehossou \\ Universite de Lorraine Faculte de Medecine \\ Noémie Roland \\ Agence Nationale de la sécurité du Médicament et des produits de Santé (ANSM) \\ Ghada Hatem \\ Maison des Femmes, Saint Denis \\ Leila Yacini \\ Centre de Sante Municipal Les Moulins, Saint Denis

\section{Laure Feldmann} \\ Centre de Santé Municipal Docteur Pesqué, Aubervilliers \\ Marie-Josèphe Saurel-Cubizolles \\ INSERM UMR1153 CRESS-EPOPe \\ Marc Bardou ( $\nabla$ marc.bardou@u-bourgogne.fr) \\ Centre Hospitalier Universitaire de Dijon https://orcid.org/0000-0003-0028-1837
}

\section{Research article}

Keywords: Family planning, Gender based violence, Health status, intimate partner violence, Sexual and reproductive health, Social deprivation

Posted Date: September 8th, 2020

DOI: https://doi.org/10.21203/rs.3.rs-64017/v1

License: (9) This work is licensed under a Creative Commons Attribution 4.0 International License. Read Full License 


\section{Abstract}

Background. Suffering violence has both short- and long-term negative effects on women's health. We set out to study the relationship between socio-demographic characteristics of women attending three Family Planning Centers (FPCs) in France and the violence they experienced and to the association between women's perception of their health status and their exposure to violence.

Methods. We conducted an observational survey of clinical practice from December 2018 to February 2019 at three FPCs in SeineSaint-Denis (lle-de-France). All women patients aged 18 years or older were eligible. We solicited data on social characteristics, precariousness, and suffering violence. We measured health status on a 10-point scales for six different symptoms.

Results. Of the 274 women who participated, $28 \%$ had experienced violence. This percentage was higher among women living in socially precarious situations compared to the not or slightly precarious (39.3\% vs $15.8 \%$, respectively). Experiencing violence was significantly associated with being between 25 and 44 years old, being in a temporary or irregular administrative situation, being unemployed or seeking a job, and being in a precarious to very precarious situation. The proportion of women reporting domestic violence was more than twice as high in those consulting in FPC-1 (42\%) than in FPC-2 (20\%) or FPC-3 (16.2\%). Regardless of age, history of violence was significantly associated with poor sleep, poor diet, low morale, and poor health in general for all FPCs and all levels of precariousness.

Conclusion. Our study reveals that reports of violence against women increased with migratory status and precariousness, unemployment or job-seeking, and a poorer state perception of one's own health in a population drawn from three Family Planning Centers in Seine-Saint-Denis. It also suggests a structure specifically dedicated to the management of women victim of violence that FPC-1, may be perceived more attractive by women exposed to domestic violence.

The study was retrospectively registered: ClinicalTrials.gov Identifier: NCT04304469

\section{Backround}

Violence against women is a profound violation of women's rights and a serious public health problem. Violence against women is defined by the United Nations as "any act of gender-based violence that results, or is likely to result, in physical, sexual or psychological harm or suffering to women, including threats of such acts, coercion or arbitrary deprivation of liberty, whether occurring in public or in private life." According to the World Health Organization (WHO), one third of women report having been exposed to physical or sexual violence by a partner or non-partner during her lifetime. The 2014 European Union Agency for Fundamental Rights (FRA) survey confirms this claim: $33 \%$ of women surveyed had survived physical and/or sexual violence by a partner, non-partner or both. In France, about 219,000 women (1\% of French women) between 18 and 75 years are victims of physical and/or sexual partner or ex-partner violence each year. These estimates likely undercount domestic violence survivors.

Violence against women has serious short- and long-term consequences for the mental, physical and sexual health of victims.' The WHO estimates that surviving violence costs women one to four years of healthy life. Reproductive health is particularly threatened since a violent partner may force sexual intercourse, not use a condom during intercourse, and restrict women's access to health care facilities. Women victims of domestic or sexual violence are more likely to seek abortions; have spontaneous miscarriages, contract sexually transmitted infections, suffer sexual dysfunction, and develop pelvic inflammatory disease than women who have not suffered violence.'

In addition, women who suffered violence have more anxiety disorders, sleep disorders, depression, post-traumatic stress disorder (PTSD); and a higher risk of suicide. They also have more sexual, gynecological, and obstetrical disorders. They have more encounters with health professionals and consume more medication (anxiolytics, analgesics) than non-violent women who have not experienced domestic violence.

The proportion of women who have survived violence among those who visit a family planning Centre (FPC) in France has not been well characterized yet, but is likely to be high especially FPCs located in poorer districts. The department with the highest poverty rate in mainland France is Seine-Saint-Denis, located next to Paris. At one of its largest hospitals, the Delafontaine Hospital 
Centre in Saint-Denis city, $58 \%$ of women who visit are in a precarious or very precarious situation. Seine-Saint-Denis was thus an ideal site for conducting the first French study to examined the relationship between social characteristics and overall health status of abused women who attend FPCs.

We set out to explore the relationship between socio-demographic characteristics, women's perception of their own health, and violence they had suffered. We included women who consulted at three FPCs in the Seine-Saint-Denis department and sought to determine their perception of their own health according to their previous experience of violence.

\section{Methods}

\section{Data sources and study population}

We carried out an observational survey of clinical practice from December 2018 to February 2019 in three FPCs in the French department of Seine-Saint-Denis: the "Maison des femmes," adjacent to and affiliated with the Delafontaine hospital (FPC-1); "Les Moulins," a municipal health center in Saint-Denis city (FPC-2); and, a municipal health center in Aubervilliers, a neighboring town (FPC-3). The Maison des Femmes (https://www.lamaisondesfemmes.fr/) is a house, adjacent to the hospital, that was created specifically to accommodate all women who are vulnerable or victims of violence. Women attending FPC1 can meet doctors, midwives, psychologists, social workers, but also police officers, lawyers, and sports and cultural leaders. This multidisciplinary team aims to accompany women in their journey by providing full medical and social support. All women aged 18 years or older were eligible. Participation was voluntary. Adult women were offered a paper questionnaire (see supplementary material); those who had difficulty understanding could ask for assistance from volunteer staff dedicated to this survey. The standardized questionnaire was identical in all three units and had four parts: 1) social and demographic characteristics, including a measure of social precariousness; 2) perceived health status; 3 ) women's knowledge about sexuality, contraception and use of voluntary termination of pregnancy; and, 4) a set of questions about violence they may have suffered.

The Committee for the Protection of Persons (CPP) of Ile de France 6 (located at Pitié-Salpêtrière Hospital, Paris) authorized this study.

Oral informed consent was obtained from all the women.

Questionnaires were self-administered and sent back to us by the women after they have left the FPC so that they did not feel pressured to answer questions with which they would feel uncomfortable.

\section{Indicators}

We included the following socio-demographic variables: place of residence; age; country of birth; administrative situation; living as a couple or not; having children; level of education; employment status; health insured; housing; and, assessment of living situation base on an individual indicator of precariousness (the Evaluation de la Précarité et des Inégalités de Santé dans les Centres d'Examens de Santé/ Evaluation of Health Precariousness and Inequalities in Health Examination Centers or EPICES score).' EPICES score is made up of 11 yes or no questions that sum up $90 \%$ of a subject's precarity. Each answer is assigned a coefficient and the 11 answers are summed to provide the EPICES score. The score is continuous, ranging from 0 (absence of precariousness) to 100 (maximum precariousness). We categorized the EPICES score into four classes corresponding to the quartiles of the overall sample.

Perceived health status was measured with the question, "How would you rate your health?". Participants responded on a Likert scale from 0 (very poor) to 10 (very good) for each of these symptoms: sleep; diet; mood; concentration; memory; and, general health. To simplify, we constructed an indicator for each system in three categories to sort responses into bad (0-4), average (5-7), or good (8-10) states. To summarize health data, we constructed an indicator by summing the scores attributed to the 6 symptoms (the global index of perceived health). The global index is graduated from 0 to 60 , and also broken into three classes that correspond to the tertiles of the global sample.

At the end of the questionnaire participants were asked about violence they may have suffered: "Currently or in the course of your life, have you suffered violence?" (yes/no). Women who had suffered violence were asked to answer these questions: "Do you think 
that this violence can have, or may have had, an impact on your health? (yes/no/don't know)" and "Have you ever been able to talk about it before? (yes/no/ don't know).

\section{Analysis strategy}

No formal sample size calculation was made as this was a pilot of the ongoing AVEC-L study. we initially planned to include 100 women in each of the FPCs.

We described the characteristics of the sample in terms of distribution frequency: socio-demographic characteristics; perceived health status; violence suffered by respondents; and, the effect violence had on their health. We used bivariate and then multivariate analyses (adjustment on age, precarious situation and center) to study the associations between socio-demographic characteristics and having suffered violence; we calculated raw odds ratios (OR) and adjusted ORs (aOR) expressed with their $95 \%$ confidence intervals $(\mathrm{Cl})$ in logistic regression models. A p value of $<0.05$ was considered significant. We expressed the relationship between having suffered violence and state of perceived health as raw and adjusted ORs, based on the 6 health status domains and the global index of perceived health.

The Pearson Chi-2 test was used to compare the percentages; statistical significance of the ORs was derived from Wald's Chi-2 test. All analyses were performed with $\mathrm{SAS} \circledast$ version 9.4 software.

\section{Results}

\section{Socio-demographic characteristics of the sample}

A total of 274 women completed the questionnaire at the three FPCs and were included in the study (100 at FPC-1; 100 at FCP-2; 74 at FPC-3). Their characteristics are summarized in Table 1. Of these, 234 (85\%), lived in Seine-Saint-Denis, 82 (30,4\%) were less than 25 years old; 143 (53.4) were born outside France, most $(n=62,23.1 \%)$ in sub-Saharan Africa; 41 (15.5\%) were in a temporary or irregular administrative situation. Only $113(42,3 \%)$ lived as a couple; $160(62 \%)$ had at least one child; $35(13 \%)$ had not reached the college level and $96(37 \%)$ had a level of education higher than a bachelor's degree. Of the women we included, 85 (33\%) were homemakers or not in the labor force and $45(18 \%)$ were seeking a job or unemployed; $86(32 \%)$ of the women lived in sheltered housing; 177 (73.1\%) were in a precarious situation. 
Table 1

Socio-demographic characteristics of the sample

\begin{tabular}{|c|c|}
\hline Characteristics of participants & Number (Percentages) \\
\hline \multicolumn{2}{|l|}{ Place of residence } \\
\hline Seine-Saint-Denis & $219(85.2)$ \\
\hline Others & $38(14.8)$ \\
\hline \multicolumn{2}{|l|}{ Age (Years) } \\
\hline$<25$ & $82(30.4)$ \\
\hline [25-34] & $94(34.8)$ \\
\hline [35-44] & $54(20.0)$ \\
\hline$\geq 45$ & $40(14.8)$ \\
\hline \multicolumn{2}{|l|}{ Country of birth } \\
\hline France & $125(46.6)$ \\
\hline Maghreb (Algeria, Morocco, Tunisia) & $53(19.8)$ \\
\hline Sub-Saharan Africa & $62(23.1)$ \\
\hline Other countries & $28(10.5)$ \\
\hline \multicolumn{2}{|l|}{ Administrative status } \\
\hline Regular administrative status & $224(84.5)$ \\
\hline Provisional or irregular administrative situation & $41(15.5)$ \\
\hline \multicolumn{2}{|l|}{ Lives as a couple } \\
\hline No & $224(57.7)$ \\
\hline Yes & $41(15.5)$ \\
\hline \multicolumn{2}{|l|}{ Has one or more children } \\
\hline No & $100(38.5)$ \\
\hline Yes & $160(61.5)$ \\
\hline \multicolumn{2}{|l|}{ If yes, number of children } \\
\hline 1 child & $40(27.0)$ \\
\hline 2 children & $51(34.5)$ \\
\hline 3 children & 29(19.6) \\
\hline 4 and more children & 28(18.9) \\
\hline \multicolumn{2}{|l|}{ Level of education } \\
\hline Out of school or primary school & $35(13.4)$ \\
\hline College & $29(11.1)$ \\
\hline High School & $101(38.7)$ \\
\hline University & $96(36.8)$ \\
\hline \multicolumn{2}{|l|}{ Employment } \\
\hline At home, inactive & 85(33.3) \\
\hline
\end{tabular}




\begin{tabular}{|ll|}
\hline Characteristics of participants & Number (Percentages) \\
\hline Looking for work, unemployed & $45(17.7)$ \\
\hline Active Busy & $125(49.0)$ \\
\hline Has health insurance & \\
\hline No & $30(11.3)$ \\
\hline Yes & $236(88.7)$ \\
\hline Housing & \\
\hline Tenant of the accommodation & $160(59.5)$ \\
\hline Owner of the accommodation & $23(8.5)$ \\
\hline Hosted & $86(32.0)$ \\
\hline Precarious situation: Epices score from 0 to 100 & \\
\hline Precariousness according to the Epices Score standard $>30$ & $177(73.1)$ \\
\hline Epices score quartiles * & \\
\hline Not precarious $<27.21$ & $59(24.4)$ \\
\hline Slightly precarious $<45.00$ & $61(25.2)$ \\
\hline Precarious $<61.00$ & $61(25.2)$ \\
\hline highly precarious $>=61.00$ & $61(25.2)$ \\
\hline
\end{tabular}

\section{Violence suffered}

Of the 274 women who answered the survey, 74 (27\%; Cl [21\%-32\%]) reported they had suffered violence. Of these, 55 (74\%) thought the violence reduced their health and 26 (35\%) had never mentioned domestic violence before this consultation.

\section{Associations between socio-demographic characteristics and having experienced violence}

Women aged 25-44 were about 3 times more likely to have suffered violence than women under 25 or over 45 (aOR of 3.32, 1.377.64 and 2.72, 1.05-7.03; for women aged 25-34 years and 35-44 years respectively), as were women in temporary/irregular administrative situation (OR, 3.56; $1.79-7.08)$ and women seeking employments or unemployed $(\mathrm{OR}, 2.54 ; 1.25-5.17)$. This likelihood of having suffered violence was almost three times higher (OR2.90; 1.54-5.44) among women consultants in FCP-1 than in the other two centers. Not living as a couple was associated with a non statiscally1.6 (OR1.64; 0.94-2.87, $p=0.082)$ increased risk of having been exposed to violence. Education degree below college was associated with the same a non statiscally 1.6 increased risk. (See Table 2 for a summary of these results.) After adjustment, women with a very precarious status (determined by EPICES score) had an almost five-fold greater risk of having experienced violence $(\mathrm{aOR}=4.99 ; 1.86-13.34)$ and women who visited FPC-1 had a three-fold higher risk of having suffered violence $(\mathrm{aOR}=3.37 ; 1.60-7.11)$. 
Table 2

Percentages of women who have experienced violence by socio-demographic characteristics and gross and adjusted odds ratios

\begin{tabular}{|c|c|c|c|c|c|}
\hline $\begin{array}{l}\text { Socio-demographic } \\
\text { characteristics }\end{array}$ & $\begin{array}{l}\text { Women who have } \\
\text { suffered violence } \\
\text { Number (Percentages) }\end{array}$ & $\begin{array}{l}\text { OR raw } \\
\text { [IC à95\%] }\end{array}$ & $p$ value & $\begin{array}{l}\text { OR adjusted for age, } \\
\text { precariousness and center, [95\% Cl] }\end{array}$ & $\begin{array}{l}\mathrm{p} \\
\text { value }\end{array}$ \\
\hline Age (Years) & 71 & 270 & 0.0093 & 239 & 0.0548 \\
\hline$<25$ & $12(14.6 \%)$ & 1 & & 1 & \\
\hline$[25-34]$ & $34(36.2 \%)$ & $\left.\begin{array}{l}3.31[1.57- \\
6.95\end{array}\right]$ & & $3.32[1.37-7.64]$ & \\
\hline$[35-44]$ & $17(31.5 \%)$ & $\begin{array}{l}2.68[1.16- \\
6.21]\end{array}$ & & $2.72[1.05-7.03]$ & \\
\hline$\geq 45$ & $8(20.0 \%)$ & $\begin{array}{l}1.46[0.54- \\
3.92]\end{array}$ & & $2.26[0.75-6.86]$ & \\
\hline Country of birth & 73 & 268 & 0.2423 & & \\
\hline France & $32(25.6 \%)$ & 1 & & & \\
\hline $\begin{array}{l}\text { Maghreb (Algeria, } \\
\text { Morocco, Tunisia) }\end{array}$ & $12(22.6 \%)$ & $\begin{array}{l}0.85[0.40- \\
1.82]\end{array}$ & & & \\
\hline sub-Saharan Africa & $23(37.1 \%)$ & $\begin{array}{l}1.71[0.98- \\
3.30]\end{array}$ & & & \\
\hline Other countries & $6(21.4 \%)$ & $\begin{array}{l}0.73[0.30- \\
2.13]\end{array}$ & & & \\
\hline $\begin{array}{l}\text { Length of stay in France } \\
\text { (immigrants) }\end{array}$ & 40 & 142 & 0.2369 & & \\
\hline Duration $\leq 3$ years & $16(37.2 \%)$ & $\begin{array}{l}2.30[0.85- \\
6.20]\end{array}$ & & & \\
\hline Duration: $[4,15]$ years & $16(26.7 \%)$ & $\begin{array}{l}1.41[0.54- \\
3.70]\end{array}$ & & & \\
\hline Duration $>15$ years & $8(20.5 \%)$ & 1 & & & \\
\hline Living as a couple & 74 & 267 & 0.0818 & & \\
\hline No & $49(31.8 \%)$ & $\begin{array}{l}1.64[0.94- \\
2.87]\end{array}$ & & & \\
\hline Yes & $25(22.1 \%)$ & 1 & & & \\
\hline Level of education & 73 & 261 & 0.5605 & & \\
\hline Out of school / primary & $12(34.3 \%)$ & $\begin{array}{l}1.66[0.71- \\
3.84]\end{array}$ & & & \\
\hline College & $10(34.5 \%)$ & $\begin{array}{l}1.67[0.68- \\
4.10]\end{array}$ & & & \\
\hline high school & $28(27.7 \%)$ & $\begin{array}{l}1.22[0.64- \\
2.31]\end{array}$ & & & \\
\hline University & $23(24.0 \%)$ & 1 & & & \\
\hline Employment & 68 & 254 & 0.0026 & & \\
\hline
\end{tabular}

*Four classes corresponding to the quartiles of the Spices score over the entire sample

Numbers below 74 (total number of women who reported having suffered violence) reflect missing data

Abbreviations: OR, odds ratio; $\mathrm{Cl}$, confidence interval 


\begin{tabular}{|c|c|c|c|c|c|}
\hline $\begin{array}{l}\text { Socio-demographic } \\
\text { characteristics }\end{array}$ & $\begin{array}{l}\text { Women who have } \\
\text { suffered violence } \\
\text { Number (Percentages) }\end{array}$ & $\begin{array}{l}\text { OR raw } \\
\text { [IC à95\%] }\end{array}$ & p value & $\begin{array}{l}\text { OR adjusted for age, } \\
\text { precariousness and center, }[95 \% \mathrm{Cl}]\end{array}$ & $\begin{array}{l}p \\
\text { value }\end{array}$ \\
\hline At home, inactive & $15(17.9 \%)$ & $\begin{array}{l}0.63[0.32- \\
1.26]\end{array}$ & & & \\
\hline $\begin{array}{l}\text { Looking for jobs- } \\
\text { unemployment }\end{array}$ & $21(46.7 \%)$ & $\begin{array}{l}2.54[1.25- \\
5.17]\end{array}$ & & & \\
\hline Workforce & $32(25,6 \%)$ & 1 & & & \\
\hline Housing & 71 & 269 & 0.0630 & & \\
\hline Personal housing & $42(22,9 \%)$ & 1 & & & \\
\hline Lodging accommodation & $29(33.7 \%)$ & $\begin{array}{l}1.71[0.97- \\
3.00]\end{array}$ & & & \\
\hline Administrative status & 72 & 265 & 0.0003 & & \\
\hline regular situation & $51(22.7 \%)$ & 1 & & & \\
\hline $\begin{array}{l}\text { temporary or irregular } \\
\text { situation }\end{array}$ & $21(51.2 \%)$ & $\begin{array}{l}3.56[1.79- \\
7.08]\end{array}$ & & & \\
\hline Precarious situation* & 67 & 242 & $<.0001$ & & 0.0071 \\
\hline Not precarious & $7(11.9 \%)$ & 1 & & 1 & \\
\hline Slightly precarious & $12(19.7 \%)$ & $\begin{array}{l}1.82[0.66- \\
4.99]\end{array}$ & & $1.18[0.60-4.92]$ & \\
\hline Precarious & $18(29.5 \%)$ & $\begin{array}{l}3.11[1.19- \\
8.14]\end{array}$ & & $2.58[0.95-7.06]$ & \\
\hline Highly precarious & $30(49.2 \%)$ & $\begin{array}{l}7.19[2.82- \\
18.31]\end{array}$ & & $4.99[1.86-13.34]$ & \\
\hline Centre & 74 & 274 & 0.0002 & & 0.0012 \\
\hline FPC1 & $42(42.0 \%)$ & $\begin{array}{l}2.90[1.54- \\
5.44]\end{array}$ & & $3.37[1.60-7.11]$ & \\
\hline FPC2 & $20(20.0 \%)$ & 1 & & 1 & \\
\hline FPC3 & $12(16.2 \%)$ & $\begin{array}{l}0.77[0.35- \\
1.70]\end{array}$ & & $0.95[0.41-2.23]$ & \\
\hline \multicolumn{6}{|c|}{ *Four classes corresponding to the quartiles of the Spices score over the entire sample } \\
\hline \multicolumn{6}{|c|}{ Numbers below 74 (total number of women who reported having suffered violence) reflect missing data } \\
\hline Abbreviations: OR, odds ra & ; Cl, confidence interval & & & & \\
\hline
\end{tabular}

\section{Perceived health status of participants}

Data on perceived health status are reported in Table 3. The sum of the six symptoms (summary of health data) gives a mean of 40 out of 60 with a standard deviation of 11.77, corresponding to "average" perceived health status. 
Table 3

Description of perceived health status, average scores and classes selected for each symptom

\begin{tabular}{|c|c|c|c|c|c|c|c|c|}
\hline & \multirow[t]{2}{*}{ number } & \multirow{2}{*}{$\begin{array}{l}\text { Average scores } \\
\text { (Standard } \\
\text { deviation) }\end{array}$} & \multicolumn{2}{|c|}{$\begin{array}{l}\text { Perceived State } \\
\text { mediocre }\end{array}$} & \multicolumn{2}{|c|}{$\begin{array}{l}\text { Perceived State } \\
\text { medium }\end{array}$} & \multicolumn{2}{|c|}{$\begin{array}{l}\text { Perceived State } \\
\text { good }\end{array}$} \\
\hline & & & Notes & number (\%) & number & $\begin{array}{l}\text { number } \\
(\%)\end{array}$ & Notes & $\begin{array}{l}\text { number } \\
(\%)\end{array}$ \\
\hline $\begin{array}{l}\text { Sleep } \\
{[0-10]}\end{array}$ & 264 & $\begin{array}{l}5.80 \\
(2.81)\end{array}$ & {$[0-4]$} & $90(34.1)$ & {$[5-7]$} & 99 (37.5) & $\begin{array}{l}{[8-} \\
10]\end{array}$ & $75(28.4)$ \\
\hline $\begin{array}{l}\text { Diet } \\
{[0-10]}\end{array}$ & 258 & $\begin{array}{l}7.37 \\
(2.76)\end{array}$ & {$[0-5]$} & $117(45.3)$ & {$[6-8]$} & $71(27.5)$ & $\begin{array}{l}{[9-} \\
10]\end{array}$ & 70 (27.1) \\
\hline $\begin{array}{l}\text { Mood } \\
{[0-10]}\end{array}$ & 259 & $\begin{array}{l}6.06 \\
(2.90)\end{array}$ & {$[0-5]$} & $97(37.4)$ & [6-8] & 93 (35.9) & $\begin{array}{l}{[9-} \\
10]\end{array}$ & $69(26.6)$ \\
\hline $\begin{array}{l}\text { Concentration } \\
{[0-10]}\end{array}$ & 261 & $\begin{array}{l}6.44 \\
(2.95)\end{array}$ & {$[0-5]$} & $118(45.2)$ & {$[6-7]$} & $59(22.6)$ & $\begin{array}{l}{[8-} \\
10]\end{array}$ & 84 (32.2) \\
\hline $\begin{array}{l}\text { Memory } \\
{[0-10]}\end{array}$ & 262 & $\begin{array}{l}7.12 \\
(2.72)\end{array}$ & {$[0-5]$} & $100(38.2)$ & [6-8] & $92(35.1)$ & $\begin{array}{l}{[9-} \\
10]\end{array}$ & 70 (26.7) \\
\hline $\begin{array}{l}\text { overall health } \\
{[0-10]}\end{array}$ & 263 & $\begin{array}{l}7.00 \\
(2.56)\end{array}$ & {$[0-5]$} & $131(49.8 \%)$ & {$[6-7]$} & $71(27.0)$ & $\begin{array}{l}{[8-} \\
10]\end{array}$ & $61(23.2)$ \\
\hline $\begin{array}{l}\text { Perceived Health Index* } \\
{[0-60]}\end{array}$ & 247 & $\begin{array}{l}40.01 \\
(11.77)\end{array}$ & $\begin{array}{l}{[0-} \\
35]\end{array}$ & $92(37.3 \%)$ & $\begin{array}{l}{[36-} \\
45]\end{array}$ & $72(29.1 \%)$ & $\begin{array}{l}{[46-} \\
60]\end{array}$ & $83(33.6 \%)$ \\
\hline
\end{tabular}


Table 4

Perceived state of health according to violence, gross and adjusted percentages and odds ratios

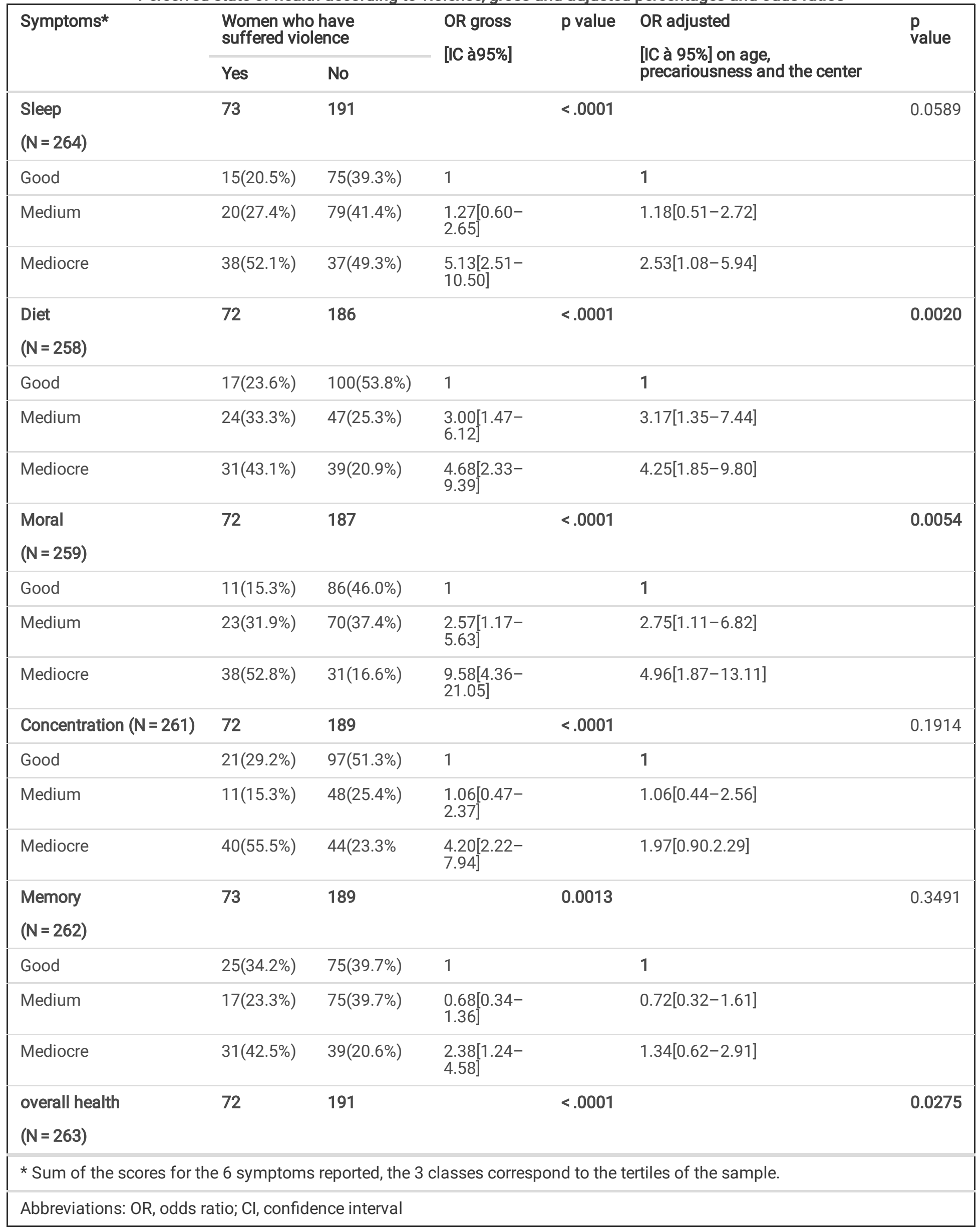




\begin{tabular}{|c|c|c|c|c|c|c|}
\hline \multirow[t]{2}{*}{ Symptoms* } & \multicolumn{2}{|c|}{$\begin{array}{l}\text { Women who have } \\
\text { suffered violence }\end{array}$} & \multirow{2}{*}{$\begin{array}{l}\text { OR gross } \\
\text { [IC à95\%] }\end{array}$} & \multirow[t]{2}{*}{$\mathrm{p}$ value } & \multirow{2}{*}{$\begin{array}{l}\text { OR adjusted } \\
\text { [IC à 95\%] on age, } \\
\text { precariousness and the center }\end{array}$} & \multirow{2}{*}{$\begin{array}{l}\mathrm{p} \\
\text { value }\end{array}$} \\
\hline & Yes & No & & & & \\
\hline Good & $23(31.9 \%)$ & $108(56.5 \%)$ & 1 & & 1 & \\
\hline Medium & $18(25.0 \%)$ & $53(27.8 \%)$ & $\begin{array}{l}1.59[0.79- \\
3.21]\end{array}$ & & $1.38[0.60-3.17]$ & \\
\hline Mediocre & $21(43.1 \%)$ & $30(15.7 \%)$ & $\begin{array}{l}4.85[2.47- \\
9.52]\end{array}$ & & $3.04[1.33-6.92]$ & \\
\hline $\begin{array}{l}\text { Perceived Health Index* } \\
(\mathrm{N}=247)\end{array}$ & 70 & 177 & & $<.0001$ & & 0.0127 \\
\hline Good & $10(14.3 \%)$ & $82(46.3 \%)$ & 1 & & 1 & \\
\hline Medium & $17(24.3 \%)$ & $55(31.1 \%)$ & $\begin{array}{l}2.53[1.08- \\
5.94]\end{array}$ & & $2.52[0.97-6.57]$ & \\
\hline Mediocre & $43(61.4 \%)$ & $40(22.6 \%)$ & $\begin{array}{l}8.82[4.02- \\
19.33]\end{array}$ & & $4.06[1.60-10.31]$ & \\
\hline \multicolumn{7}{|c|}{ * Sum of the scores for the 6 symptoms reported, the 3 classes correspond to the tertiles of the sample. } \\
\hline Abbreviations: OR, odd & o; $\mathrm{Cl}$, cont & ce interval & & & & \\
\hline
\end{tabular}

\section{Association between having experienced violence and perceived health status}

Having experienced violence was significantly associated with reporting poor sleep $(\mathrm{OR}=5.13[2.51-10.50])$, poor nutrition $(\mathrm{OR}=$ 4.68 [2.33-9.39]), bad mood ( $O R=9.58$ [4.36-21]), poor concentration $(O R=4.20[2.2-7.94])$, bad memory $(O R=2.38[1.24-4.58])$, poor health in general $(\mathrm{OR}=4.85[2.47-9.52])$, and poor index of perceived health $(\mathrm{OR}=8.82[4.02-19.33])$.

After adjusting for age, FPC and level of insecurity, having suffered violence was associated with a more than 2.5 greater risk bad sleep $(\mathrm{aOR}=2.53$ [1.08-5.94]), a more than 3 greater risk of reporting poor general health $(\mathrm{aOR}=3.04$ [1.33-6.92]), and a more than 4 greater risk of having a poor diet $(\mathrm{aOR}=4.25[1.85-9.80])$, bad mood ( $\mathrm{aOR}=4.96[1.87-13.11])$, or poor perceived health index $(\mathrm{aOR}=4.06$ [1.60-10.31]). See Table 2 for a detailed summary.

\section{Discussion}

Violence was associated with reduced perceived state of health in the women we surveyed.

More than one fourth of women (27\%) who visited the three FPCs claimed to have suffered violence at least once in their lives.

Despite being close to each other and all located in the same deprived area, the proportion of women reporting domestic violence in FPC1 (42.0\%) was more than twice as high as in FPC2(20.0\%) or in FPC3 (16.2\%). Women aged 25-34 years and 35-44 years were around 3 times more likely than women below 25 years or above 45 years of having experienced violence in their lifetime. Women from Sub-Saharan Africa had a 1.71 higher risk of violence (unadjusted $O R=1.71 ; 0.98-3.30$ ); this rate was 2.3 higher among those who arrived in France less than 3 years ago than those who arrived in France more than 15 years ago (unadjusted OR $=2.30 ; 0.85-6.20)$.

Our finding that $27 \%$ of women had suffered violence, a proportion slightly higher than the $23 \%$ rate reported in a study conducted in France in $2009,{ }^{16}$ and close to the $30 \%$ reported by the WHO. We also reported higher prevalence of violence perpetrated by a partner or ex-partner than was found by studies in other countries, ranging from $4.0 \%$ in Australia ${ }^{12}$ to $11.4 \%$ in India. But these studies only surveyed violence women suffered in the past year, while we considered lifetime history of violence. A European prevalence study found a lifetime prevalence of violence by a partner of $6.1 \%$, which is much lower than in our result.

In our study, women aged 25-44 years were most likely to have suffered violence in their lifetime. International studies published in the past decade report that youth is an individual risk factor for suffering violence in women." Women under the age of 25 years are 
the most likely to experience violence, including sexual violence. ${ }^{26}$ Our questionnaire asked women of all ages about their lifetime history of violence so, even if the pattern of abuse of younger women holds true, older women were still more likely to have experienced violence in their lifetimes than younger women. Younger women may also more likely to minimize domestic violence, which intensifies and changes modalities over time. Older women may thus be more ready and able to identify domestic violence. We may hypothesize that young women who attend FPCs may be more likely to visit to obtain contraception or end undesired pregnancies, and may turn elsewhere if they are victims of violence. A study by Sanz-Barbero et al., ${ }^{26}$ using the same definition of exposure to domestic violence as ours found that the prevalence of domestic violence was greater among women aged between 18 and 24 years. These discrepancies in both prevalence and risk factors illustrate the very partial knowledge we have on the subject and argue in favor of continuing observational studies in different contexts.

The association between low socio-economic level and higher risk of violence against women is often mentioned in the literature. Our results support the argument that women in vulnerable social situations are at increased risk of violence, especially related to precariousness, unemployment or job search, and immigrant status with irregular administrative status. In the major reference survey in France on violence against women ENVEFF (Enquête Nationale sur les Violences Faites aux Femmes en France), the women most exposed to violence were unemployed, retired, or working part-time. In violent relationships, the aggressor is often economically dominant and may make it difficult his partner to seek and hold a steady job. Financial independence is an obstacle to fleeing an abusive relationship. Aggressors may perceive a partner's search for a job as a manifestation of autonomy, which could trigger domestic violence.

Immigrant status is a risk factor for violence, whether in the country of origin, during migration route, or in the country of arrival. Our study aligns with other studies of immigration and violence that have demonstrated this. Immigrant women are often dependent upon their partner (confiscation of papers, lack of economic independence) and may find it hard to seek help (language barrier, social isolation, reluctance to call the police in irregular situations). Gender inequalities, a source of reproductive violence, may also be more marked in an immigrant's country of origin. Cultural factors affect feelings of shame, fear of stigmatization, and perceptions of violence and knowledge of the possibilities of external aid. ${ }^{-}$

Family Planning Center 1, La Maison des Femmes, is a house specifically dedicated to the management of vulnerable women or women exposed to violence. It offers care combining the health, social and judicial aspects in a single place. As FPC-1 is more than twice as likely than the 2 others, despite all being in the same deprived Paris' conurbation, our study suggests that the "Maison des Femmes" has achieved its first objective, i.e. to be well identified by the some women of the department and neighboring departments as a preferred structure for dealing with violence.

Our finding that the women in our study reported poorer health status if they had a history of violence aligns with the results of many international studies that found abused women suffered more mental and physical health problems than women who were not victims of domestic violence. In particular, they have more anxiety disorders, sleep disorders, depression, post-traumatic stress disorder (PTSD)'and a higher risk of suicide. They also have more sexual, gynecological, and obstetrical disorders.

\section{Study limitations}

Our study was limited by the small number of participants (274) so we could not make a detailed comparison of the characteristics of women from each of the three centers. The on-going AVEC-L study will increase the number of included women in order to strengthened robustness of our background results. Women may minimize or fail to identify violence in self-reports, which may lead to classification bias. Our survey did not ask women to share a chronology of violence or specify the types of violence, severity or repetition, and we did not ask them to classify their aggressors. This may explain the discrepancy as for example Sanz-Barbero et al. suggested that if younger women are more frequently exposed to intimate partner violence, these are of less severity. ${ }^{26}$ Selection bias may also be present; it is possible that women who refused to answer may have suffered more violence than by women who were willing to complete the survey. But this is unlikely because the rate of violence reported here is at least of the same magnitude than in the international literature.

This cross-sectional study does not allow us to conclude on causal links between antecedents of violence, socio-demographic characteristics and the health status perceived by the women respondents.

Page $12 / 16$ 
A cross-sectional study is not designed to identify causal links between antecedents of violence, socio-demographic characteristics, and perceived health status. A causal link between level of precariousness and surviving violence is impossible to draw from this data, and the causal connection may run in either direction or both. The amplitude of association may be the sum of an effect in both directions. Causal relationship between poor health and a history of violence is equally hard to determine. The relationship between health status and surviving violence against may be cumulative (the more traumatic episodes a woman experiences, the greater the impact on her health), adaptive (a woman's environment and experience may positively or negatively modulate the effects of violence on her health over the short and long term).

Data obtained in this study and in the on-going AVEC-L study will provide robust background evidence to assess the medical and social utility of structures specifically dedicated to the management of domestic violence like "La Maison-des-Femmes" (FPC1)

\section{Conclusion}

Our study reveals that reports of violence against women increased with migratory status and precariousness, unemployment or job-seeking, and a poorer state perception of one's own health in a population drawn from three Family Planning Centers in SeineSaint-Denis.

\section{Abbreviations}

CPF: Family Planning Center

Cl: confidence interval

CPP: Comité de protection des personnes.

Abortion: Voluntary termination of pregnancy

WHO: World Health Organization

OR : Odd ratio

\section{Declarations}

\section{- Ethical approval:}

Our study was approved by the Committee for the Protection of Persons (CPP) lle-de-France VI (Groupe Hospitalier Pitié-Salpêtrière), reference number 92-19 NI Cat.3, dossier number 19.12.10.36712

\section{- Consent to publication:}

Not applicable

\section{- Availability of data and materials:}

"The datasets used and/or analyzed during the current study are available from the corresponding author on reasonable request."

\section{- Competing interests:}

None

The authors declare they have no competing interests.

\section{- Funding:}


The study was funded by crowed funding and promoted by the Dijon Bourgogne's Teaching hospital.

\section{- Authors' contributions:}

YA contributed to designing the study, carrying out the study, analyzing the data, interpreting the findings and writing the article. MJS, NR, MB and GH contributed to formulating the research question, designing the study, interpreting the findings and writing the article. LY and LF contributed to interpreting the findings and proofreading the article

\section{- Acknowledgments:}

We thank the women who agreed to participate in the study, the staff who ran the interviews with women, and Miss Kali Tal for her editorial support,

\section{References}

1. WHO. Violence against women. [Accessed August 10, 2020]. https://www.who.int/news-room/fact-sheets/detail/violenceagainst-women

2. UN Women. Defining Violence against Women and Girls. [Accessed August 10, 2020]. https://www.endvawnow.org/en/articles/295-dfinition-de-la-violence-contre-les-femmes-et-les-filles.html

3. WHO. Violence against women: a 'global health problem of epidemic proportions'. World Health Organization; [Accessed August 10, 2020]. https://www.who.int/mediacentre/news/releases/2013/violence_against_women_20130620/en/

4. FRA. Violence against women: an EU wide survey. Main results. Vienne, 2012. 4p. [Accessed August 10, 2020]. https://fra.europa.eu/en/publications-and-resources/data-and-maps/survey-data-explorer-violence-against-women-survey

5. SSMSI. Living Environment and Safety Investigation Report 2018. Victimization, delinquency and feelings of insecurity. Inter Stats, 2018. [Accessed August 10, 2020]. https://www.interieur.gouv.fr/Interstats/L-enquete-Cadre-de-vie-et-securiteCVS/Rapport-d-enquete-cadre-de-vie-et-securite-2018

6. MIPROF. Domestic violence and sexual violence in France in 2017. Annual indicators. La lettre de l'observatoire national des violences faites aux femmes $n^{\circ} 13,2018$. [Accessed August 10, 2020] .

https://www.stopviolencesfemmes.gouv.fr/IMG/pdf/violences_au_sein_du_couple_et_violences_sexuelles_novembre_2018.pdf

7. Coker AL, Davis KE, Arias I, et al. Physical and mental health effects of intimate partner violence for men and women. Am J Prev Med. 2002;23(4):260-268. doi:10.1016/s0749-3797(02)00514-7

8. Campbell JC. Health consequences of intimate partner violence. The Lancet 2002; 359:1331-1336

9. Krug E et al. World Report on Violence and Health. WHO, Geneva, 2002. 376p. [Accessed August 10, 2020] https://www.who.int/violence_injury_prevention/violence/world_report/en/full_fr.pdf

10. Miller, Elizabeth, Beth Jordan, Rebecca Levenson, et Jay G. Silverman. « Reproductive Coercion: Connecting the Dots Between Partner Violence and Unintended Pregnancy ». Contraception 81, $n^{\circ} 6$ (juin 2010):

457-59. https://doi.org/10.1016/j.contraception.2010.02.023

11. Coker, A. Does physical intimate partner violence affect sexual health ? A systematic review. Trauma Violence Abuse, 2007; 8 (2), p. 149-177.

12. Fanslow J. Silva M. Whitehead, A. Robinson E. Pregnancy outcomes and intimate partner violence in New Zealand. Australian and New Zealand Journal of Obstetrics and Gynaecology, 2008; 48 (4), p. 391-397

13. Sharman LS, Douglas H, Price E, Sheeran N, Dingle GA. Associations Between Unintended Pregnancy, Domestic Violence, and Sexual Assault in a Population of Queensland Women. Psychiatr Psychol Law. 2018;26(4):541-552. Published 2018 Oct 24. doi:10.1080/13218719.2018.1510347

14. Hunter T, Botfield JR, Estoesta J, Markham P, Robertson S, McGeechan K. Experience of domestic violence routine screening in Family Planning NSW clinics. Sex Health. 2017;14(2):155-163. doi:10.1071/SH16143

15. Pengpid, S., Peltzer, K. Associations of physical partner violence and sexual violence victimization on health risk behaviours and mental health among university students from 25 countries. BMC Public Health 2020;20, 937. 
https://doi.org/10.1186/s12889-020-09064-y

16. Beydoun \& al. Intimate Partner Violence against adult women and its association with major depressive disorder, depressive symptoms and post-partum depression: a systematic review and meta-analysis. Social Science \& Medecine, 1982; 75 (6) : $959-$ 75.

17. McCauley J, Kern DE, Kolodner K, Dill L, Schroeder AF, DeChant HK, Ryden J, Bass EB, Derogatis LR. The "battering syndrome": prevalence and clinical characteristics of domestic violence in primary care internal medicine practices. Annals of Internal Medicine 1995;123:737-746.

18. Jaspard M., Brown E., Condon S. \& al. Naming and counting violence against women: a first national survey in France. Population et Sociétés, 2001; 364, pp. 1-4.

19. Silverman J.G, Decker M, Reed E, Raj A. Intimate partner violence victimization prior to and during pregnancy among women residing in 26 US : associations with maternal and neonatal helath. American Journal of Obstetrics and Gynecology (2006) $195,140-8$.

20. Stark E, Flitcraft AH. Women and children at risk: a feminist perspective on child abuse. Int J Health Serv. 1988;18(1):97-118.

21. Bayardin V. \& al. In lle de France, poverty has intensified in the territories already most exposed. INSEE, Paris, 2017 (76). https://www.insee.fr/fr/statistiques/3291402

22. St Denis Hospital Center. The hospital is setting up a generalizable econometric study on precariousness and non-recovery. Entre Nous, St Denis, 2016 (13). [Accessed August 10, 2020] http://www.ch-stdenis.fr/media-files/entrenous-n-13-mars2016,232.pdf

23. Bihan $\mathrm{H}$, Laurent $\mathrm{S}$, Sass $\mathrm{C}$, et al. Association between individual deprivation, glycemic control and diabetic complications The EPICES score. Diabetes Care $2005 ; 28: 2680-5$

24. Guilloteau A, Binquet C, Bourredjem A, Fournel I, Lalanne-Mistrih ML, Nacher M, \& al. Social deprivation among socio-economic contrasted French areas: Using item response theory analysis to assess differential item functioning of the EPICES questionnaire in stroke patients. PLoS One 2020;15:e0230661.

25. Chen GL, Silverman JG, Dixit A, et al. A cross-sectional analysis of intimate partner violence and family planning use in rural India. EClinicalMedicine. 2020;21:100318. Published 2020 Apr 18. doi:10.1016/j.eclinm.2020.100318

26. Sanz-Barbero B, Barón N, Vives-Cases C. Prevalence, associated factors and health impact of intimate partner violence against women in different life stages. PLoS One. 2019;14(10):e0221049. Published 2019 Oct 9. doi:10.1371/journal.pone.0221049

27. World Health Organization (WHO), London School of Hygiene and Tropical Medicine. Preventing intimate partner and sexual violence against women. Taking action and generating evidence. Genève: World Health Organization, 2010

28. Abramsky T, Watts CH, Garcia-Moreno C, Devries K, Kiss L, Ellsberg M, et al. What factors are associated with recent intimate partner violence? findings from the WHO multi-country study on women's health and domestic violence. BMC Public Health 2011;11:109

29. David Martín-Baena et al. Violence against young women attending primary care services in Spain: prevalence and health consequences. Family Practice, 2015; 32(4): 381-86, https://doi.org/10.1093/fampra/cmv017.

30. Maciel, M. N. A., Blondel, B., \& Saurel-Cubizolles, M.-J. Physical Violence During Pregnancy in France: Frequency and Impact on the Health of Expectant Mothers and New-Borns. Maternal and Child Health Journal, 2019; 23(8): 1108-

16. doi:10.1007/s10995-019-02747-y

31. Jaspard M, Les violences contre les femmes. Paris, La Découverte, coll « Repères », 2011, 128 pages.

32. Amanor-Boadu Y, Messing JT, Stith SM, Anderson JR, O'Sullivan CS, Campbell JC. Immigrant and nonimmigrant women: factors that predict leaving an abusive relationship. Violence Against Women. 2012;18(5):611-633.

doi:10.1177/1077801212453139

33. United Nations Development Programme. Human Development Reports. Gender Inequality Index. 2017 [Accessed August 10, 2020] http://hdr.undp.org/en/composite/GII

34. Liang B, Goodman L, Tummala-Narra P, Weintraub S. A theoretical framework for understanding help-seeking processes among survivors of intimate partner violence. American Journal of Community Psychology, 2005;36:71-84 
35. Overstreet NM, Quinn DM. The Intimate Partner Violence Stigmatization Model and Barriers to Help-Seeking. Basic App/ Soc Psych. 2013;35(1):109-122. doi:10.1080/01973533.2012.746599

36. Géry Y. The Maison des femmes responds to a need for comprehensive care of violence. Health in action. Paris, 2017: 439: p.47-9.

37. Dillon G, Hussain R, Loxton D, Rahman S. Mental and Physical Health and Intimate Partner Violence against Women: A Review of the Literature. Int J Family Med. 2013;2013:313909. doi:10.1155/2013/313909

38. Pengpid, S., Peltzer, K. Associations of physical partner violence and sexual violence victimization on health risk behaviours and mental health among university students from 25 countries. BMC Public Health 2020;20, 937.

https://doi.org/10.1186/s12889-020-09064-y

39. Beydoun \& al. Intimate Partner Violence against adult women and its association with major depressive disorder, depressive symptoms and post-partum depression: a systematic review and meta-analysis. Social Science \& Medecine, 1982; 75 (6) : 959 75.

40. McCauley J, Kern DE, Kolodner K, Dill L, Schroeder AF, DeChant HK, Ryden J, Bass EB, Derogatis LR. The "battering syndrome": prevalence and clinical characteristics of domestic violence in primary care internal medicine practices. Annals of Internal Medicine 1995;123:737-746.

41. Jaspard M., Brown E., Condon S. \& al. Naming and counting violence against women: a first national survey in France. Population et Sociétés, 2001; 364, pp. 1-4.

42. Silverman J.G, Decker M, Reed E, Raj A. Intimate partner violence victimization prior to and during pregnancy among women residing in 26 US : associations with maternal and neonatal helath. American Journal of Obstetrics and Gynecology (2006) $195,140-8$.

\section{Supplementary Files}

This is a list of supplementary files associated with this preprint. Click to download.

- AhogbehossouYetalAVECLquestionnairetranslated.docx 